\title{
Cell-based neurorestorotherapy in amyotrophic lateral sclerosis - scientific truth should rely on facts, but not conjecture
}

\author{
Lin Chen ${ }^{1,2}$, Haitao $\mathrm{Xi}^{1,2}$ and Hongyun Huang ${ }^{1,2,3 *}$ \\ ' Cell Research Center, Beijing Hongtianji Neuroscience Academy, Beijing, China \\ 2 Department of Neurosurgery, Beijing Rehabilitation Center, Beijing, China \\ ${ }^{3}$ Division of Neurorestoratology, Yuquan Hospital, Tsinghua University, Beijing, China \\ *Correspondence: hongyunh@gmail.com
}

\section{A commentary on}

No benefits from experimental treatment with olfactory ensheathing cells in patients with ALS

by Piepers, S., and van den Berg, L. H. (2010). Amyotroph. Lateral Scler. 11, 328-330.

\section{INTRODUCTION}

Amyotrophic lateral sclerosis (ALS) is a progressive, fatal, neurodegenerative disease caused by the degeneration of motor neurons, the nerve cells in the central nervous system that control voluntary muscle movement. Death due to respiratory failure occurs typically $2-5$ years after disease onset (Suzuki et al., 2007). Our basic and clinical studies have proven that OECs have neuroprotective effect and can improve quality of life and prolong surviving time (Huang et al., 2007, 2008; Chen et al., 2007, 2012; Li et al., 2011). Dr. Piepers (Piepers and van den Berg, 2010) published a paper to make comment on our work, in which there were some wrong viewpoints and errors. Also there may be someone sharing same viewpoints with his paper. In order to avoid misleading readers, it is our irresistible duty to tell people the truth what happened about treatment study, show more evidences, and facts of development for this disease. Herein, we encourage people to read his original paper with our thoughts in mind. We strongly believe that scientific truth should rely on facts, but not conjecture.

“THESE THERAPIES AIM AT NEURONAL REPLACEMENT OR USE EMBRYONIC OR NEURONAL STEM CELLS TO PREVENT DYSFUNCTIONAL MOTOR NEURONS FROM DYING" IS CORRECT?

In fact, the mechanisms for neurorestoration in ALS are very complex, which lie on neural regeneration, repair, and replacement of damaged components of the nervous system, neuroplasticity, neuroprotection and neuromodulation, vasculogenesis, and recovery mechanisms of immune regulation (Fornai et al., 2008; IANR, 2009; Mitrecić et al., 2009; Huang et al., 2010). Embryonic or neuronal stem cells hardly replace motor neuron in ALS and also are difficult to have useful functions as people expect. Otherwise, transplanted cells can serve as a source of trophic factors providing neuroprotection, slowing down neuronal degeneration, and disease progression. Presently, cell-based neurorestorative treatment has become a new trend (Huang, 2010). Rapidly increasing worldwide data have proven that it has a pivotal therapeutic value in ALS (see Tables 1 and 2; Chen et al., 2012). So neruoprotection is one of the most functional neurorestorative strategies for ALS; unfortunately Dr. Piepers fully ignored most of the progress in this research field.

\section{WHAT IDEAL EXPECTATION OF TREATMENT IS AND WHAT CURRENT MEDICINE CAN DO FOR ALS?}

To attenuate the rate of deterioration should be considered and encouraged as the main aim at the current time, because the cure has not yet been made available so far. So any improvement is very important for patients with ALS. Based on Dr. Piepers' paper, we at least found three out of a total of seven patients who had reversed their functions after our treatment. Our recent study, multiple transplantations for ALS shows that every single treatment could make functional improvement for patients (Table 3; Chen et al., 2012). These essential findings should be translated as highlighted positive results because specialists in the ALS study community around the whole world know there is no way to reverse the clinical course of ALS through routine treatment including Rilutek. People should not require current medicine to get treatment results as their ideal expectation for some untreatable diseases such as ALS.

\section{WHERE SHOULD THE CELLS BE TRANSPLANTED INTO?}

We can understand why Dr. Piepers said that "it is difficult to understand how focal injection of OECs into the corona radiata of ALS patients would result in improved function of motor neurons that are not in close proximity to the injection site." We compared two ways by transplanting cells into spinal cord or brain; and there was no difference of functional improvement between two methods (Chen et al., 2007). We are also doing experimental study which will be published soon. People will know more about the progress in this field from our current experimental study, that is, OEC transplantation in corona radiate prolongs the survival of SOD1-G93A rats with protection to not only the upper motor neurons but lower motor neurons in cornu anterius medullae spinalis as well.

\section{“IT HAS BEEN SHOWN THAT INJECTING STEM CELLS INTO THE SPINAL CORD OF ALS PATIENTS IS TECHNICALLY FEASIBLE AND SAFE" IS CORRECT?}

It is well known that the spinal cord surgery under the general anesthesia has more risks in ALS patients, so we have improved our treatment from the initial intraspinal cord transplantation since over 5 years ago. Our clinical study proved that local anesthesia and stereotactic procedure has much less body damage for ALS patients 
Table 1 | Selected preclinical literatures of cell-based therapy for ALS (data from Pubmed; modified from 5).

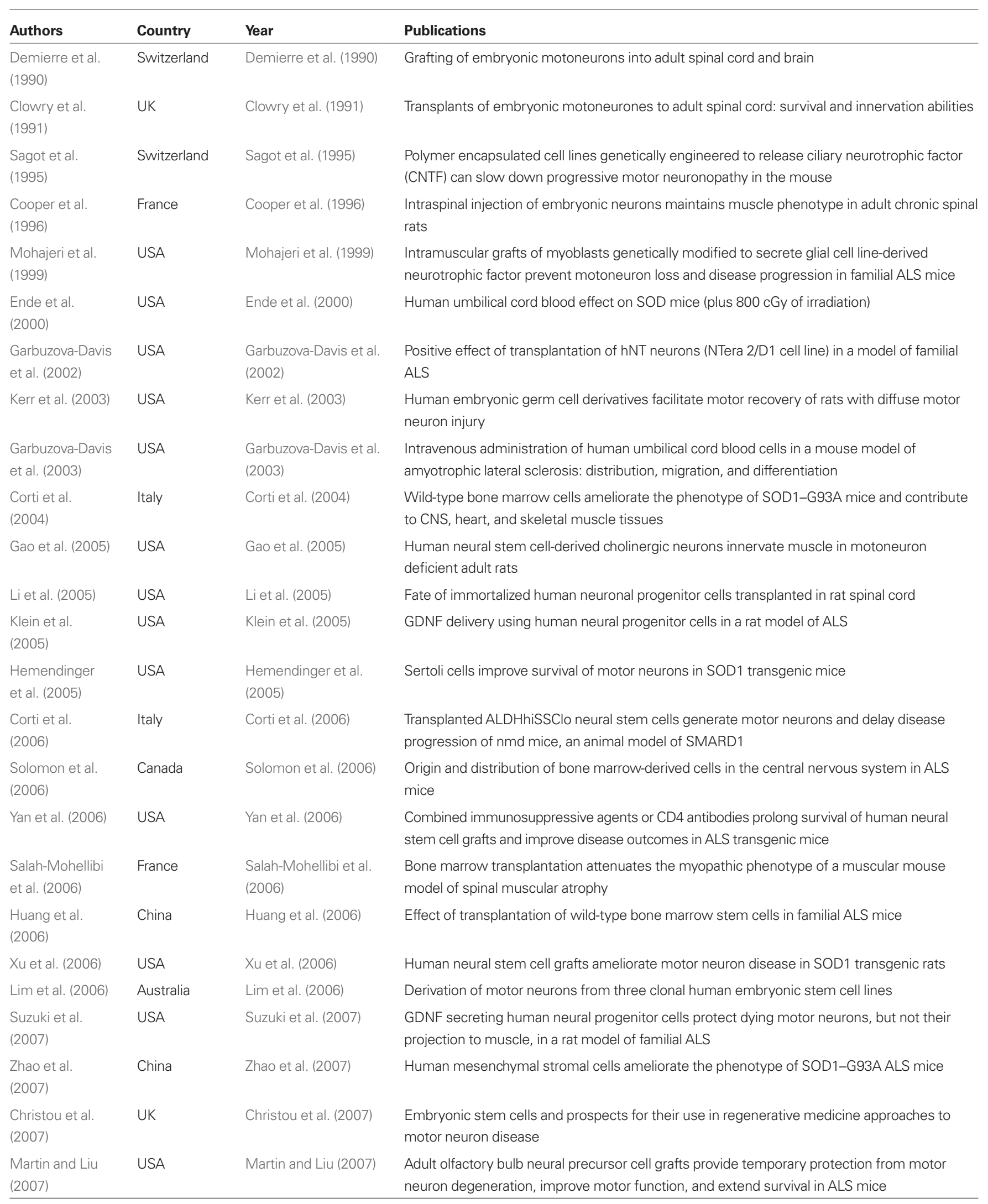


Table 1 | Continued

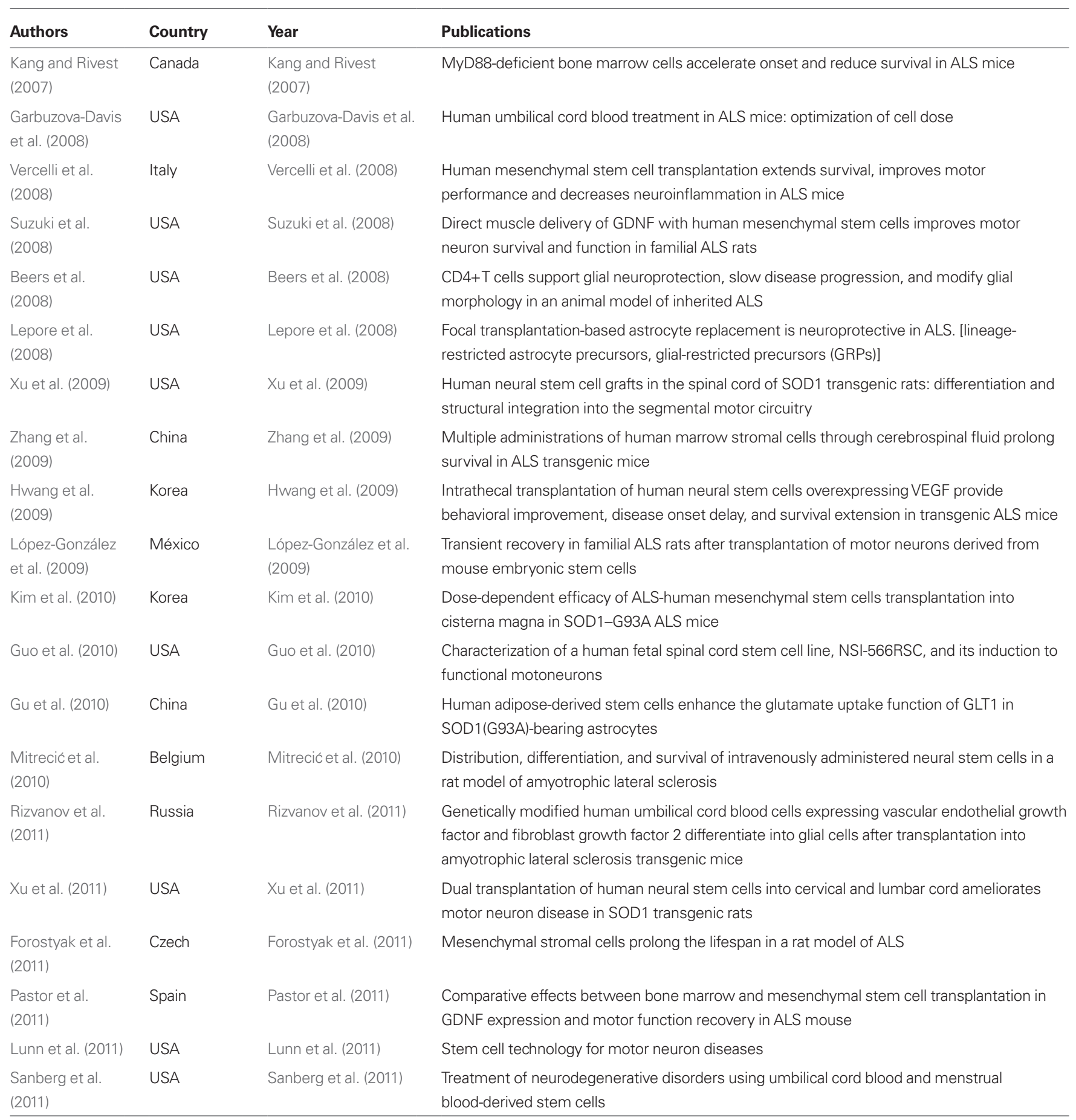

than general anesthesia and open spinal surgery (Chen et al., 2007). We suggest that Dr. Piepers should do more clinical investigations or get clinical experience before he comments or discusses on which method is better, feasible, and safe for clinical issue.

\section{IMMUNOSUPPRESSANT IS NECESSARY?}

The application of immunosuppressant remains controversial after cell transplantation into the brain and/or spinal cord. In additional, some of the ALS patients are too weak to tolerate the drugs. Most recently, OECs were able to stay alive for at least 12-24 months which has been proven through two autopsies by Italian physicians (Giordana et al., 2010).

In summary, to talk by conjecture is a simple process; however, to really help patients with ALS to improve their neurological functions and quality of life must face 
Table 2 | Literatures of cell-based therapy in ALS humans (data from Pubmed; modified from 5).

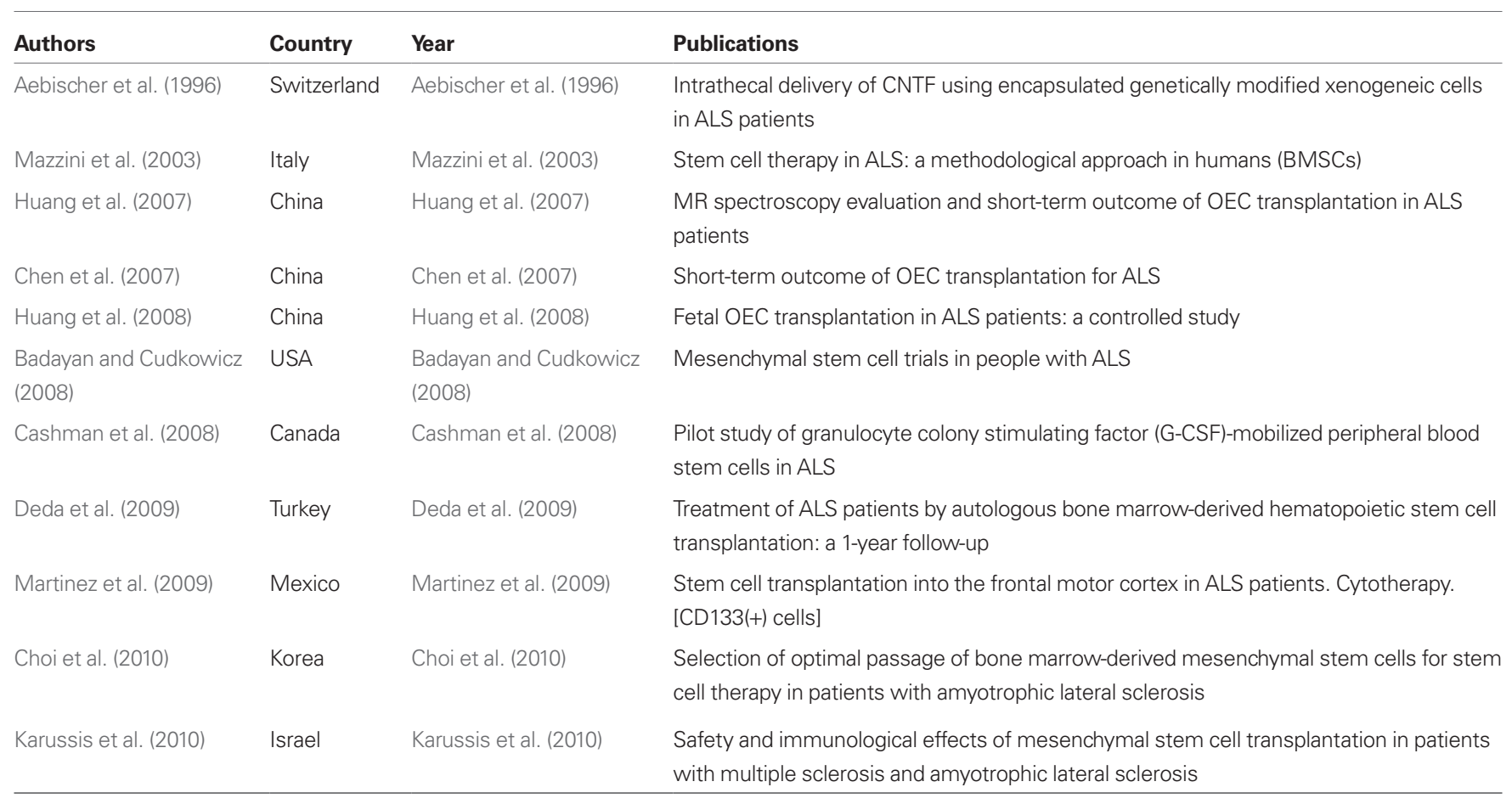

Table 3 | Amyotrophic lateral sclerosis-FRS and Norris scale score and increased score after four treatments.

\begin{tabular}{|c|c|c|c|c|c|c|}
\hline \multirow[t]{2}{*}{ Cell transplant } & \multicolumn{3}{|c|}{ ALS-FRS } & \multicolumn{3}{|c|}{ Norris scale } \\
\hline & Pre-treatment & Post-treatment & Increased score & Pre-treatment & Post-treatment & Increased score \\
\hline 2nd & $20.1 \pm 7.3$ & $21.1 \pm 7.4$ & $1.1 \pm 1.3$ & $43.0 \pm 21.6$ & $45.6 \pm 21.8$ & $2.3 \pm 0.2 .9$ \\
\hline $3 r d$ & $18.3 \pm 7.7$ & $19.4 \pm 8.4$ & $1.1 \pm 1.5$ & $36.1 \pm 20.9$ & $39.6 \pm 23.1$ & $3.4 \pm 0.6 .9$ \\
\hline 4th & $20.5 \pm 4.9$ & $20.5 \pm 4.9$ & $0.0 \pm 0.0$ & $37.5 \pm 24.7$ & $40.05 \pm 28.3$ & $2.5 \pm 0.3 .5$ \\
\hline
\end{tabular}

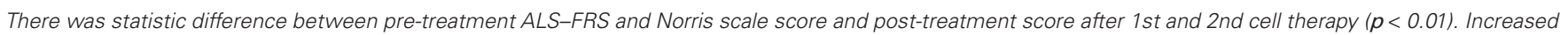

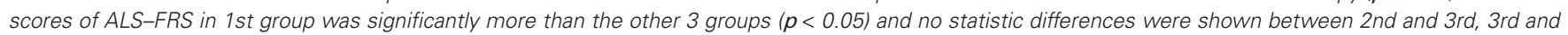

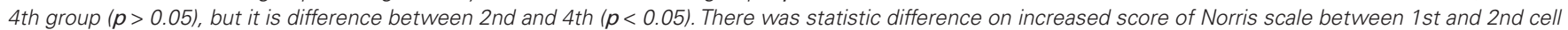
transplant $(p=0.019)$.

hardships and challenges. The community should encourage any efforts to discover effective therapeutic strategies globally. Fortunately, now clinical studies already showed that cell therapy could restore patients' neurological functions by neuroprotection or some other mechanisms.

\section{REFERENCES}

Aebischer, P., Schluep, M., Déglon, N., Joseph, J. M., Hirt, L., Heyd, B., Goddard, M., Hammang, J. P., Zurn, A. D., Kato, A. C., Regli, F., and Baetge, E. E. (1996). Intrathecal delivery of CNTF using encapsulated genetically modified xenogeneic cells in amyotrophic lateral sclerosis patients. Nat. Med. 2, 696-699.

Badayan, I., and Cudkowicz, M. E. (2008). Is it too soon for mesenchymal stem cell trials in people with ALS? Amyotroph. Lateral Scler. 9, 321-322.
Beers, D. R., Henkel, J. S., Zhao, W., Wang, J., and Appel, S. H. (2008). CD4+T cells support glial neuroprotection, slow disease progression, and modify glial morphology in an animal model of inherited ALS. Proc. Natl. Acad. Sci. U.S.A. 105, 15558-15563.

Cashman, N., Tan, L. Y., Krieger, C., Mädler, B., Mackay, A., Mackenzie, I., Benny, B., Nantel, S., Fabros, M., Shinobu, L., Yousefi, M., and Eisen, A. (2008). Pilot study of granulocyte colony stimulating factor (G-CSF)-mobilized peripheral blood stem cells in amyotrophic lateral sclerosis (ALS). Muscle Nerve $37,620-625$.

Chen, L., Chen, D., Xi, H., Wang, Q., Liu, Y., Zhang, F., Wang, H., Ren, Y., Xiao, J., Wang, Y., and Huang, H. (2012). Olfactory ensheathing cell neurorestorotherapy for amyotrophic lateral sclerosis patients, benefits from multiple transplantations. Cell Transplant.20.(in press).

Chen, L., Huang, H., Zhang, J., Zhang, F., Liu, Y., Xi, H., Wang, H., Gu, Z., Song, Y., Li, Y., and Tan, K. (2007). Short-term outcome of olfactory ensheathing cells transplantation for treatment of amyotrophic lateral sclerosis. Zhongguo Xiu Fu Chong Jian Wai Ke Za Zhi 21, 961-966.

Choi, M. R., Kim, H. Y., Park, J. Y., Lee, T. Y., Baik, C. S., Chai, Y. G., Jung, K. H., Park, K. S., Roh, W., Kim, K. S., and Kim, S. H. (2010). Selection of optimal passage of bone marrow-derived mesenchymal stem cells for stem cell therapy in patients with amyotrophic lateral sclerosis. Neurosci. Lett. 472, 94-98.

Christou, Y. A., Moore, H. D., Shaw, P. J., and Monk, P. N. (2007). Embryonic stem cells and prospects for their use in regenerative medicine approaches to motor neurone disease. Neuropathol. Appl. Neurobiol.33,485-498.

Clowry, G., Sieradzan, K., and Vrbová, G. (1991). Transplants of embryonic motoneurones to adult spinal cord, survival and innervation abilities. Trends Neurosci. 14, 355-357.

Cooper, R. N., Feraboli-Lohnherr, D., Butler-Browne, G., Orsal, D., Gimenez, Y., Ribotta, M., and Privat, A. (1996). Intraspinal injection of embryonic neurons maintains muscle phenotype in adult chronic spinal rats. J. Neurosci. Res. 46, 324-329. 
Corti, S., Locatelli, F., Donadoni, C., Guglieri, M., Papadimitriou, D., Strazzer, S., Del Bo, R., and Comi, G. P. (2004). Wild-type bone marrow cells ameliorate the phenotype of SOD1-G93A ALS mice and contribute to CNS, heart and skeletal muscle tissues. Brain 127, 2518-2532.

Corti, S., Locatelli, F., Papadimitriou, D., Donadoni, C., Del Bo, R., Crimi, M., Bordoni, A., Fortunato, F., Strazzer, S., Menozzi, G., Salani, S., Bresolin, N., and Comi, G. P. (2006). Transplanted ALDHhiSSClo neural stem cells generate motor neurons and delay disease progression of NMD mice, an animal model of SMARD1. Hum. Mol. Genet. 15, 167-187.

Deda, H., Inci, M. C., Kürekçi, A. E., Sav, A., Kayihan, K., Ozgün, E., Ustünsoy, G. E., and Kocabay, S. (2009). Treatment of amyotrophic lateral sclerosis patients by autologous bone marrow-derived hematopoietic stem cell transplantation, a 1-year follow-up. Cytotherapy 11, 18-25.

Demierre, B., Ruiz-Flandes, P., Martinou, J. C., and Kato, A. C. (1990). Grafting of embryonic motoneurons into adult spinal cord and brain. Prog. Brain Res. 82, 233-237.

Ende, N., Weinstein, F., Chen, R., and Ende, M. (2000). Human umbilical cord blood effect on sod mice (amyotrophic lateral sclerosis). Life Sci. 67, 53-59.

Fornai, F., Longone, P., Cafaro, L., Kastsiuchenka, O., Ferrucci, M., Manca, M. L., Lazzeri, G., Spalloni, A., Bellio, N., Lenzi, P., Modugno, N., Siciliano, G. Isidoro, C., Murri, L., Ruggieri, S., and Paparelli, A. (2008). Lithium delays progression of amyotrophic lateral sclerosis. Proc. Natl. Acad. Sci. U.S.A. 105, 2052-2057.

Forostyak, S., Jendelova, P., Kapcalova, M., Arboleda, D., and Sykova, E. (2011). Mesenchymal stromal cells prolong the lifespan in a rat model of amyotrophic lateral sclerosis. Cytotherapy 13, 1036-1046.

Gao, J., Coggeshall, R. E., Tarasenko, Y. I., and Wu, P. (2005). Human neural stem cell-derived cholinergic neurons innervate muscle in motoneuron deficient adult rats. Neuroscience 131, 257-262.

Garbuzova-Davis, S., Sanberg, C. D., Kuzmin-Nichols, N., Willing, A. E., Gemma, C., Bickford, P. C., Miller, C., Rossi, R., and Sanberg, P. R. (2008). Human umbilical cord blood treatment in a mouse model of ALS, optimization of cell dose. PLoS ONE 3, e2494. doi: 10.1371/journal.pone.0002494

Garbuzova-Davis, S., Willing, A. E., Milliken, M., Saporta, S., Zigova, T., Cahill, D. W., and Sanberg, P. R. (2002). Positive effect of transplantation of hNT neurons (NTera 2/D1 cell-line) in a model of familial amyotrophic lateral sclerosis. Exp. Neurol. 174, 169-180.

Garbuzova-Davis, S., Willing, A. E., Zigova, T., Saporta, S., Justen, E. B., Lane, J. C., Hudson, J. E., Chen, N., Davis, C. D., and Sanberg, P. R. (2003). Intravenous administration of human umbilical cord blood cells in a mouse model of amyotrophic lateral sclerosis, distribution, migration, and differentiation. J. Hematother. Stem Cell Res. 12, 255-270.

Giordana, M. T., Grifoni, S., Votta, B., Magistrello, M., Vercellino, M., Pellerino, A., Navone, R., Valentini, C., Calvo, A., and Chiò, A. (2010). Neuropathology of olfactory ensheathing cell transplantation into the brain of two amyotrophic lateral sclerosis (ALS) patients. Brain Pathol. 20, 730-737.

Gu, R., Hou, X., Pang, R., Li, L., Chen, F., Geng, J., Xu, Y., and Zhang, C. (2010). Human adipose-derived stem cells enhance the glutamate uptake function of
GLT1 in SOD1(G93A)-bearing astrocytes. Biochem. Biophys. Res. Commun. 393, 481-486.

Guo, X., Johe, K., Molnar, P., Davis, H., and Hickman, J. (2010). Characterization of a human fetal spinal cord stem cell line, NSI-566RSC, and its induction to functional motoneurons. J. Tissue Eng. Regen. Med. 4, 181-193.

Hemendinger, R., Wang, J., Malik, S., Persinski, R., Copeland, J., Emerich, D., Gores, P., Halberstadt, C., and Rosenfeld, J. (2005). Sertoli cells improve survival of motor neurons in SOD1 transgenic mice, a model of amyotrophic lateral sclerosis. Exp. Neurol. 196, 235-243.

Huang, H. (2010). Neurorestoratology, a distinct discipline and a new era: a brief introduction to the first IANR section. Cell Transplant. 19, 129-131.

Huang, H., Chen, L., and Sanberg, P. (2010). Cell therapy from bench to bedside translation in CNS Neurorestoratology era. Cell Med. 1, 15-46.

Huang, H., Chen, L., Xi, H., Wang, H., Zhang, J., Zhang, F., and Liu, Y. (2008). Fetal olfactory ensheathing cells transplantation in amyotrophic lateral sclerosis patients, a controlled pilot study. Clin. Transplant. $22,710-718$.

Huang, H., Tan, K., Chen, L., Xue, Y., Wang, H., Xi, H., Liu, Y., Zhang, F., and Zhang, J. (2007). MR spectroscopy evaluation and short-term outcome of olfactory ensheathing cells transplantation in amyotrophic lateral sclerosis patients. Zhongguo Xiu Fu Chong Jian Wai Ke Za Zhi 21, 52-57.

Huang, H., Zhang, C., Zhao, C. P., Yao, X. L., and Xi, J. (2006). Effect of transplantation of wild-type bone marrow stem cells in mouse model of familial amyotrophic lateral sclerosis. Zhongguo Yi Xue Ke Xue Yuan Xиe Bao 28, 562-566.

Hwang, D. H., Lee, H. J., Park, I. H., Seok, J. I., Kim, B. G., Joo, I. S., and Kim, S. U. (2009). Intrathecal transplantation of human neural stem cells overexpressing VEGF provide behavioral improvement, disease onset delay and survival extension in transgenic ALS mice. Gene Ther. 16, 1234-1244.

International Association of Neurorestoratology (IANR). (2009). Beijing declaration of international association of neurorestoratology. Cell Transplant. $18,487$.

Kang, J., and Rivest, S. (2007). MyD88-deficient bone marrow cells accelerate onset and reduce survival in a mouse model of amyotrophic lateral sclerosis. J. Cell Biol. 179, 1219-1230.

Karussis, D., Karageorgiou, C., Vaknin-Dembinsky, A. Gowda-Kurkalli, B., Gomori, J. M., Kassis, I., Bulte, J. W., Petrou, P., Ben-Hur, T., Abramsky, O., and Slavin, S. (2010). Safety and immunological effects of mesenchymal stem cell transplantation in patients with multiple sclerosis and amyotrophic lateral sclerosis Arch. Neurol. 67, 1187-1194.

Kerr, D. A., Lladó, J., Shamblott, M. J., Maragakis, N. J., Irani, D. N., Crawford, T. O., Krishnan, C., Dike, S., Gearhart, J. D., and Rothstein, J. D. (2003). Human embryonic germ cell derivatives facilitate motor recovery of rats with diffuse motor neuron injury. $J$. Neurosci. 23, 5131-5140.

Kim, H. Y., Choi, M. R., Hwang, S., Nam, K. H., Kim, H. C., Han, J. S., Kim, K. S., Yoon, H. S., and Kim, S. H. (2010). Dose-dependent efficacy of ALS-human mesenchymal stem cells transplantation into cisterna magna in SOD1-G93A ALS mice. Neurosci. Lett. 468 , 190-194.
Klein, S. M., Behrstock, S., McHugh, J., Hoffmann, K., Wallace, K., Suzuki, M., Aebischer, P., and Svendsen, C. N. (2005). GDNF delivery using human neural progenitor cells in a rat model of ALS. Hum. Gene Ther. 16, 509-521.

Lepore, A. C., Rauck, B., Dejea, C., Pardo, A. C., Rao, M. S., Rothstein, J. D., and Maragakis, N. J. (2008). Focal transplantation-based astrocyte replacement is neuroprotective in a model of motor neuron disease. Nat. Neurosci. 11, 1294-1301.

Li, P., Tessler, A., Han, S. S., Fischer, I., Rao, M. S., and Selzer, M. E. (2005). Fate of immortalized human neuronal progenitor cells transplanted in rat spinal cord. Arch. Neurol. 62, 223-229.

Li, Y., Bao, J., Khatibi, N. H., Chen, L., Wang, H., Duan, Y., Huang, H., and Zhou, C. (2011). Olfactory ensheathing cell transplantation into spinal cord prolongs the survival of mutant SOD1(G93A) ALS rats through neuroprotection and remyelination. Anat. Rec. (Hoboken) 294, 847-857.

Lim, U.M., Sidhu, K. S., and Tuch, B.E. (2006). Derivation of motor neurons from three clonal human embryonic stem cell lines. Curr. Neurovasc. Res. 3, 281-288.

López-González, R., Kunckles, P., and Velasco, I. (2009). Transient recovery in a rat model of familial amyotrophic lateral sclerosis after transplantation of motor neurons derived from mouse embryonic stem cells. Cell Transplant. 18, 1171-1181.

Lunn, J. S., Sakowski, S. A., Federici, T., Glass, J. D., Boulis, N.M., and Feldman, E. L. (2011). Stem cell technology for the study and treatment of motor neuron diseases. Regen. Med. 6, 201-213.

Martin, L. J., and Liu, Z. (2007). Adult olfactory bulb neural precursor cell grafts provide temporary protection from motor neuron degeneration, improve motor function, and extend survival in amyotrophic lateral sclerosis mice. J. Neuropathol. Exp. Neurol. 66, 1002-1018.

Martinez,H. R., Gonzalez-Garza, M.T., Moreno-Cuevas, J. E., Caro, E., Gutierrez-Jimenez, E., and Segura, J. J. (2009). Stem-cell transplantation into the frontal motor cortex in amyotrophic lateral sclerosis patients. Cytotherapy 11, 26-34.

Mazzini, L., Fagioli, F., Boccaletti, R., Mareschi, K., Oliveri, G., Olivieri, C., Pastore, I., Marasso, R., and Madon, E. (2003). Stem cell therapy in amyotrophic lateral sclerosis, a methodological approach in humans. Amyotroph. Lateral Scler. Other Motor Neuron Disord. 4, 158-161.

Mitrecić, D., Gajović, S., and Pochet, R. (2009). Toward the treatments with neural stem cells, experiences from amyotrophic lateral sclerosis. Anat. Rec. 292, 1962-1967.

Mitrecić, D., Nicaise, C., Gajović, S., and Pochet, R. (2010). Distribution, differentiation, and survival of intravenously administered neural stem cells in a rat model of amyotrophic lateral sclerosis. Cell Transplant. 19, 537-548.

Mohajeri, M. H., Figlewicz, D.A., and Bohn, M. C. (1999). Intramuscular grafts of myoblasts genetically modified to secrete glial cell line-derived neurotrophic factor prevent motoneuron loss and disease progression in a mouse model of familial amyotrophic lateral sclerosis. Hum. Gene Ther. 10, 1853-1866.

Pastor, D., Viso-León, M. C., Jones, J., Jaramillo-Merchán, J., Toledo-Aral, J. J., Moraleda, J. M., and Martínez, S. (2011). Comparative effects between bone marrow and mesenchymal stem cell transplantation in 
GDNF expression and motor function recovery in a motorneuron degenerative mouse model. Stem Cell. Rev. PMID: 21717132. [Epub ahead of print].

Piepers, S., and van den Berg, L. H. (2010). No benefits from experimental treatment with olfactory ensheathing cells in patients with ALS. Amyotroph. Lateral Scler. 11, 328-330.

Rizvanov, A. A., Guseva, D. S., Salafutdinov, I. I., Kudryashova, N,V., Bashirov, F. V., Kiyasov, A. P., Yalvaç, M. E., Gazizov, I. M., Kaligin, M. S., Sahin, F., Mukhamedyarov, M. A., Palotás, A., and Islamov, R. R. (2011). Genetically modified human umbilical cord blood cells expressing vascular endothelial growth factor and fibroblast growth factor 2 differentiate into glial cells after transplantation into amyotrophic lateral sclerosis transgenic mice. Exp. Biol. Med. (Maywood) 236, 91-98.

Sagot, Y., Tan, S.A., Baetge, E., Schmalbruch, H., Kato, A. C., and Aebischer,P.(1995). Polymer encapsulated cell lines genetically engineered to release ciliary neurotrophic factor (CNTF) can slow down progressive motor neuronopathy in the mouse. Eur. J. Neurosci. 7, 1313-1322.

Salah-Mohellibi, N., Millet, G., André-Schmutz, I., Desforges, B., Olaso, R., Roblot, N., Courageot, S. Bensimon, G., Cavazzana-Calvo, M., and Melki, J. (2006). Bone marrow transplantation attenuates the myopathic phenotype of a muscular mouse model of spinal muscular atrophy. Stem Cells 24, 2723-2732.

Sanberg, P. R., Eve, D. J., Willing, A. E., Garbuzova-Davis, S., Tan, J., Sanberg, C. D., Allickson, J. G., Cruz, L. E., and Borlongan, C. V. (2011). The treatment of neurodegenerative disorders using umbilical cord blood and menstrual blood-derived stem cells. Cell Transplant. 20, 85-94.
Solomon, J. N., Lewis, C. A., Ajami, B., Corbel, S. Y., Rossi, F. M., and Krieger, C. (2006). Origin and distribution of bone marrow-derived cells in the central nervous system in a mouse model of amyotrophic lateral sclerosis. Glia 53, 744-753.

Suzuki, M., McHugh, J., Tork, C., Shelley, B., Hayes, A. Bellantuono, I., Aebischer, P., and Svendsen, C. N. (2008). Direct muscle delivery of GDNF with human mesenchymal stem cells improves motor neuron survival and function in a rat model of familial ALS. Mol. Ther. 16, 2002-2010.

Suzuki, M., McHugh, J., Tork, C., Shelley, B., Klein, S. M., Aebischer, P., and Svendsen, C. N. (2007). GDNF secreting human neural progenitor cells protect dying motor neurons, but not their projection to muscle, in a rat model of familial ALS. PLoS ONE 2, e689. doi: 10.1371/journal.pone.0000689

Vercelli, A., Mereuta, O. M., Garbossa, D., Muraca, G., Mareschi, K., Rustichelli, D., Ferrero, I., Mazzini, L., Madon, E., and Fagioli, F. (2008). Human mesenchymal stem cell transplantation extends survival, improves motor performance and decreases neuroinflammation in mouse model of amyotrophic lateral sclerosis. Neurobiol. Dis. 31, 395-405.

Xu, L., Ryugo, D. K., Pongstaporn, T., Johe, K., and Koliatsos, V.E. (2009). Human neural stem cell grafts in the spinal cord of SOD1 transgenic rats, differentiation and structural integration into the segmental motor circuitry. J. Comp. Neurol. 514, 297-309.

Xu, L., Shen, P., Hazel, T., Johe, K., and Koliatsos, V. E. (2011). Dual transplantation of human neural stem cells into cervical and lumbar cord ameliorates motor neuron disease in SOD1 transgenic rats. Neurosci. Lett. 494, 222-226.
Xu, L., Yan, J., Chen, D., Welsh, A. M., Hazel, T., Johe, K., Hatfield, G., and Koliatsos, V.E. (2006). Human neural stem cell grafts ameliorate motor neuron disease in SOD-1 transgenic rats. Transplantation 82, 865-875.

Yan, J., Xu, L., Welsh, A. M., Chen, D., Hazel, T., Johe, K., and Koliatsos, V. E. (2006). Combined immunosuppressive agents or CD4 antibodies prolong survival of human neural stem cell grafts and improve disease outcomes in amyotrophic lateral sclerosis transgenic mice. Stem Cells 24, 1976-1985.

Zhang, C., Zhou, C., Teng, J. J., Zhao, R. L., Song, Y. Q., and Zhang, C. (2009). Multiple administrations of human marrow stromal cells through cerebrospinal fluid prolong survival in a transgenic mouse model of amyotrophic lateral sclerosis. Cytotherapy 11, 299-306.

Zhao, C. P., Zhang, C., Zhou, S. N., Xie, Y.M., Wang, Y.H., Huang, H., Shang, Y. C., Li, W. Y., Zhou, C., Yu, M. J. and Feng, S.W. (2007). Human mesenchymal stromal cells ameliorate the phenotype of SOD1-G93A ALS mice. Cytotherapy 9, 414-426.

Received: 04 November 2011; accepted: 29 November 2011; published online: 20 December 2011.

Citation: Chen L, Xi H and Huang H (2011) Cell-based neurorestorotherapy in amyotrophic lateral sclerosis scientific truth should rely on facts, but not conjecture. Front. Integr. Neurosci. 5:83. doi: 10.3389/fnint.2011.00083 Copyright (C) 2011 Chen, Xi and Huang. This is an openaccess article distributed under the terms of the Creative Commons Attribution Non Commercial License, which permits non-commercial use, distribution, and reproduction in other forums, provided the original authors and source are credited. 